\title{
Advancing English Language Learners' Speaking Skills Using VoiceThread in Mobile Learning for Russian Tertiary Context
}

\author{
Maria Zemlyanova, University of Tyumen, Russia \\ Natalia Muravyeva, University of Tyumen, Russia \\ Svetlana Masterskikh, University of Tyumen, Russia \\ Lyudmila Shilova, University of Tyumen, Russia \\ Anna Shevtsova, University of Tyumen, Russia
}

\section{ABSTRACT}

This research examines the effectiveness of using the VoiceThread (VT) application (both web and mobile-based) for the development of oral English skills of Russian university students. The study involved 44 full-time bachelor students in non-linguistic departments. The results were evaluated by online questionnaire using SurveyMonkey. The survey indicated that the majority of students agreed that mobile VoiceThread developed their oral language skills $(M=4.75)$ and they enjoyed using it for language learning $(M=4.13)$. The novelty of the research lies in a more integral assessment of the entire set of oral linguistic skills as a result of their development using a specific mobile learning platform widely used throughout the world. The results can be used in practice to implement mobile learning platforms for teaching oral language skills to students with basic knowledge of a foreign language.

\section{KEYWORDS}

Foreign Language, Learning Application, Mobile Learning, Oral Skills in English

\section{INTRODUCTION}

Due to increasing demands for university graduates to acquire effective communicative skills in the English language, the ability to speak coherently and intelligibly in a variety of contexts has become the main goal for English language learners. Mobile communication has become one of the most frequent and widespread contexts (Zeng, 2015). As numerous studies have shown, the majority of Russian students learning English as a core subject at non-linguistic universities experience more difficulties with speaking abilities than with other language skills, which is natural under modern educational conditions at Russian universities. Similar problems with the difficulty of mastering the oral skills of English as a second language are observed in many countries (Anwas et al., 2020). Firstly, the effectiveness of university language education is highly dependent on the backgrounds of school language education. In Russia, most first-year students are unable to communicate in English and have lack of motivation. The second problem is the reduction of English language classes in the university

\section{DOI: 10.4018/IJWLTT.286754}

This article published as an Open Access article distributed under the terms of the Creative Commons Attribution License (http://creativecommons.org/licenses/by/4.0/) which permits unrestricted use, distribution, and production in any medium, provided the author of the original work and original publication source are properly credited. 
curriculum (Vulfovich, 2017). Another, no less important, reason is rooted to teaching methods and techniques mostly focused on developing reading and writing skills. Consequently, there is lack of time devoted to speaking activities in the classroom. There is also a problem of little speaking practice outside the classroom (Dahlstrom-Hakki et al., 2020; Safargalina, 2018). At the same time, the volume of visual perception of information in English, especially through mobile devices, is very large and increases every day (Virtanen \& Rasi, 2016; Suartama et al., 2020). Therefore, the challenge is for English language teachers to provide learning environment promoting desired learning outcomes. This is made possible, to large extent, by Web 2.0 mainly with access to its services through mobile platforms (Virtanen \& Rasi, 2016; Sahin Kizil, 2017).

In recent years, Web 2.0 has changed the nature of learning and teaching English as a foreign language. They have blurred the barriers between content producers and consumers and has changed attention from access to information to access to other communication (Kirby \& Hulan, 2016). Mobile web-tools have the potential to enhance active and meaningful learning, critical thinking skills, provides opportunities for interactive and collaborative learning, and increase student engagement in the classroom (Brezeanu, 2020; Crompton, 2017; Kirby \& Hulan, 2016; Okello-Obura \& Ssekito, 2015; Sahin Kizil, 2017). One of the Web 2.0 applications effectively used in speaking and listening learning is VoceThread. It gives foreign language learners a chance to practice speaking in a nonintimidating environment and collaborate with other emerging language speakers (Palmer, 2019). The essential advantage of this platform is the full functionality in the form of a mobile application for all operating systems. This article aims to determine the effect of implementing VoiceThread (VT) for enhancing learner speaking skills at University environment in Russia, as in many other countries.

\section{Literature Review}

Over the past decade, research has demonstrated several approaches to foreign language learning and teaching through VT. VT is a mobile and Web 2.0 application focused on users' collaborative conversations around digital videos, documents, images or their combinations (Kirby \& Hulan, 2016; Xie, 2016). VT consists of slides and its recording, annotating, sharing, and commenting features allow students to complete various tasks aiming at speaking development. Using internet platforms with mobile capabilities often provides an even greater choice of learning options and opportunities than classroom activities (Averkieva \& Kachalov, 2020; Bower, 2015). Students can simply record themselves naming just objects, they can record a sentence or a text about the image, they can leave comments in a form of an audio message, a video, a text, and a doodling tool enabling to draw attention and highlight the specific part in the slide.

There are many reports on foreign language learning through VoiceThread in the literature, some examples of which are as follows studies provided empirical evidence of successful using VT to enhance students' listening comprehension in the foreign language classroom (Kirby \& Hulan, 2016; Delmas, 2017; Dugartsyrenova \& Sardegna, 2017). Researches reports on the project of students' creation mobile digital stories and sharing and discussing them with their peers using VT. His findings show that VT is a creative and useful tool for the ESL classroom and it equipped with access to technology (Delmas, 2017). VT as innovative technological tool increasing students' motivation and engagement can be also used to activate learning for students with disabilities (Kirby \& Hulan, 2016). Dahlstrom-Hakki et al. (2020) and have incorporated mobile tools to gain more speaking practice outside the classroom. VoiceThread as a means of formative assessment was the purpose of Kirby and Hulan (2016) action research project. The research results turned out to be moderately positive. Students became very interested in listening to the VoiceThread and using VT as a formative assessments tool, they appreciated the opportunities to speak English outside class and showed significant progress in language skills. Thus, as numerous studies have shown, VoiceThread in foreign language environment can be effectively used to improve students' language acquisition. However, much of this research is too broadly focused on the international student and on language skills in general, and not on the explicit needs of language learners from specific countries. Without 
research focusing on the needs of students under the same learning and teaching conditions, it is difficult to make recommendations for enhancing language education of these very students (Yanagi $\&$ Baker, 2016). In the case of the current study, this focus is on Russian non-linguistic university students.

A close look at the literature on implementing mobile VT in foreign language learning reveals its main features that meet English language learners and teachers needs and requirements at Russian university environment. The first benefit of using mobile VT is its interactive attributes that activate learning no time and space constraints of the training classroom (Kirby \& Hulan, 2016). Among university students in Russia there are many English language learners who are often considered passive learners. Due to mobile VT, they can become more actively involved through an ongoing interaction with the instructional content as well as their peers. Secondly, asynchronous features of mobile VT allow students to interact with less anxiety and more confidence (Dugartsyrenova \& Sardegna, 2017). In Russian English learning classrooms, there are often learners who are shy about speaking in the target language. Mobile VT using allows students to go back and change their speech as many times as they like before sharing it with their teachers and peers. In addition, mobile VT is a great source to provide verbal feedback. The majority of Russian students have positive comments from their peers. Such comments increase students' confidence and make them feel validated. Thirdly, educators who reported positive results after using mobile VT in learning environment noted that it promoted student motivation and positive attitude toward the learning process (Delmas, 2017; Brezeanu, 2020). This benefit is crucial for Russia and many developing countries as a great number of students have low language learning motivation whereas motivated and satisfied students are more likely to get desired outcomes like "improving learning" and "academic success" (Scibora et al., 2018). The fourth main benefit of VT is its flexibility (Kirby \& Hulan, 2016). It can be used in many educational settings enabling students to communicate and collaborate around a variety of topics. Consequently, educators are able to adapt it to the curriculum, which is very important for teachers as we have to follow strict established syllabus while teaching the English language at universities. Finally, VT allows student to have speech practice in the classroom, outside the classroom, and, which is more, to participate in learning communities and engage in conversations around issues of mutual interest (Kirby \& Hulan, 2016; Barhoumi, 2017; Delmas, 2017).

\section{Purpose of the Present Study}

The present study attempts to find out whether or not implementing mobile version of VT in English learning as a foreign language has any significant influence on the improvement of speaking skills of students under modern educational conditions from Russian non-linguistic university. It also aims to investigate students' attitudes toward the use of mobile VT in their learning of English as a core subject at University. Accordingly, the following research questions were proposed:

1) What are the effects of the use of mobile VC on students' speaking skills in English?

2) What are the students' attitudes toward implementing mobile VT in and out of class to enhance speaking skills?

\section{MATERIAL AND METHODS}

\section{Participants}

The participants in this investigation were 44 full-time bachelor students in non-linguistic departments of University of Tyumen, Russia. 14 students (12 females and 2 males) were enrolled in the control class. These students were engaged in English learning process without the use of mobile version of VT. A total of 30 students ( 15 females and 7 males) were enrolled in two treatment classes (with 15 students in each), which used mobile VT throughout the course as a way to develop speaking 
skills and ultimately English language learning. All students were with pre-intermediate level. The majority of students were Russian (84\%), and there were also students from Kazakhstan, Uzbekistan, and Ukraine. The students were all in their late teens and early twenties. The nationality and the age of students were not analyzed with regard to the native language or the students' age. The data are given as additional information in the research.

The control and the treatment classes were taught by two different educators, whereas the basic approach and content were identical for all classes. Both educators are experienced English language teachers who have been teaching English as a foreign language at universities in Russia for more than 10 years. Both educators used similar teaching methods and followed the same syllabus and materials except for the implementing mobile learning practices in VT for the treatment groups.

\section{Instruments}

\section{Speaking Skills Assessments}

English speaking skills of the students were assessed by an interlocutor and assessor at the beginning and at the end of the experiment. Each student was engaged into communication with the interlocutor on one and the same topic, while the assessor preformed the analytic scoring, which aim was "to separate out salient features of performance and to evaluate each one individually and independently on its own subscale" (Taylor \& Galaczi, 2011, pp. 177). Therefore, several distinct criteria can be used within analytic rubrics (Allen \& Tanner, 2006). For this research, the five analytic criteria were comprised of fluency, content, pronunciation, grammar, and vocabulary, some of which were adapted from previous studies (Davies, 1999; Metruk, 2018).

The fluency category referred to the ability to speak smoothly and at an appropriate speed, without any unnatural pauses focusing on the message rather than the language.

The content category included the ability to accomplish the purpose of communication choosing appropriate responses to questions and statements.

The pronunciation criteria measured intelligibility, correct pronunciation of individual phonemes along with proper use of stress and intonation.

The main focus of grammar and vocabulary section was directed towards both accuracy and range.

The participants could achieve the minimum of one and the maximum of five points within each category, which accounted for the total of 25 points.

\section{Students' Attitude And Engagement Questionnaire}

To investigate students' attitude towards the use of mobile VT and its impact on their speaking skills this study adopted an on-line questionnaire using SurveyMonkey with 30 participants of the treatment groups (Abd Halim et al., 2018). The questionnaire comprised 8 closed-ended items on a 5-point Likert-type scale (strongly agree, agree, neutral, disagree, strongly disagree), which were derived from items from previous questionnaire studies (Regmi et al., 2016; Abd Halim et al., 2018).

\section{Procedure}

At the beginning of the research all students from the control and treatment groups were randomly assigned a topic on which they were required to communicate with the interlocutor in order to test their speaking skills. The assessor awarded points to the candidate for their performance and calculated the total mark. Afterwards, each candidate was provided with informative feedback on their performance within every category.

Afterwards, the control and both treatment groups met face to face each week for four hours 14 weeks in the Autumn semester, 2017. Students from the treatment groups were informed by the teacher that they were required to use predominantly mobile VT weekly to perform a speaking task outside the class. Each task required students to record their speech on the specific topic to response to certain visual image posted by the teacher, peers or students themselves for that particular VT (See 
Appendix A for an example of such a task). They were encouraged to speak for at least 2 minutes and to record as many times as they liked, before uploading the final version. The second part of the assignment was to comment at least on three other students' speeches. The aim of the task was to encourage participants to practice their speaking skills out of class when they were less likely to speak English. The feedback we provided to students after every post was based on fluency, content, pronunciation, grammar, and vocabulary. At the end of the semester final assessment of students' speaking skills similar to entrance speaking test was conducted in order to find out if the use of mobile VT had any positive effect on students' ability to communicate in English.

After final speaking test students of the treatment groups completed a 5-point Likert-type questionnaire and were instructed to state their level of agreement with each item from Strongly Agree to Strongly Disagree. (See Appendix B). In addition, they wrote a reflection letter expressing their personal attitude to the use of mobile VT as a means of advancing their speaking skills.

\section{Data Analysis}

The quantitative data analysis of the analytic scoring of students' speaking skills with the scores for each category (fluency, content, pronunciation, grammar, and vocabulary) was carried out by counting total points for each participant for both pre- and posttests. All the analytic scoring marks were compiled into a data sheet. In order to evaluate a statistical difference between the pre and posttests the mean and standard deviation were calculated. Statistical analyses were performed using STATISTICA Version 6.0.

The quantitative data of the Likert-scale items was analyzed throught an online tool Survey Monkey, which determined the number of participants who agreed or disagreed (whether strongly agreed, agreed, neutral, disagree, strongly disagree) with a certain item.

The qualitative data analysis was accomplished by identifying common ideas expressed by the participants in their reflection letters. The students' responses to mobile VT in the reflection letters were compiled according to the opinions.

\section{RESULTS}

\section{Speaking Skills Assessment}

Table 1 shows the descriptive statistics for both control and treatment groups on the pre- and postspeaking tests.

Table 1. Descriptive statistics of the Pre- and Post-tests for both groups

\begin{tabular}{|l|l|l|l|l|}
\hline & & N & Mean & Std. Deviation (SD) \\
\hline \multirow{3}{*}{ Pretest } & Treatment & 30 & 17,27 & 9,72 \\
\cline { 2 - 6 } & Control & 14 & 16,93 & 9,30 \\
\hline \multirow{3}{*}{ Posttest } & Treatment & 30 & 21,03 & 8,10 \\
\cline { 2 - 5 } & Control & 14 & 18,5 & 8,42 \\
\hline
\end{tabular}

The data from the results in the table illustrates that both groups demonstrated improvement in their speaking skills. The mean for the pretest for the control group $(\mathrm{N}=14)$ is $16,93(\mathrm{SD}=9,30)$, and for the treatment group $(\mathrm{N}=30)$ is $17,27(\mathrm{SD}=9,72)$. The mean of the scores for the posttest for the control group is $18,5(\mathrm{SD}=8,42)$ and for the treatment group is $21,03(\mathrm{SD}=8,10)$. 
In order to identify whether or not there was a difference between the results of both groups on pre and posttests, the Mann-Whitney $U$ test was implemented. Median latencies in treatment and control groups on pre-test were 17,5 and 16,5; the distributions in the two groups differed insignificantly (Mann-Whitney $U=0,5795, \mathrm{P}<0.05$ ). Median latencies in treatment and control groups on post-test were 21,5 and 17,5; so the distributions in the two groups differed significantly (Mann-Whitney $U$ $=2,482, \mathrm{P}<0.05)$. It means that there is a statistically significant difference between the treatment and control group. Thus, the research results indicate that the use of mobile VT in treatment groups influenced greater overtime on the speaking skill of students.

\section{Results From The Students' Attitude Questionnaire And Reflection Letters}

Students of the treatment group answered close ended questions related to their use of mobile version of VoiceThread and expressed their attitude to it. The survey indicated that the majority of participants agreed or strongly agreed that mobile Voice Thread helped develop their speaking skills $(M=4.75)(Q$ $2,3,6,7)$ and they enjoyed using mobile VT for language learning $(M=4,13)(\mathrm{Q} 1,8,9,10)$. As a result students reported that their recordings on mobile VoiceThread were more meaningful and well thought $(\mathrm{M}=3.98)(\mathrm{Q} 7)$, thus, it means that their preparation for submitting a response on mobile VoiceThread was more intensive. These also correlates with additional speaking practice before submitting the assignment $(\mathrm{M}=3.82)(\mathrm{Q} 4)$. These students also pointed out that they learned from their classmates' responses. ( $\mathrm{M}=3.53)(\mathrm{Q} 5)$. Eighteen out of thirty agreed that the chance to listen to other students' contributions before posting their own responses helped them to develop their own speaking skills.

As a feedback to the practice on mobile Voice Thread 30 students of treatment groups expressed their opinion about the use of mobile Voice Thread as a mean for advancing speaking skills. To a large extent, students highly appreciated their experience of using mobile VT and found it engaging, motivating and enjoyable. The majority of respondents acknowledged that VoiceThread required more preparation and effort. They needed the extra practice in rehearsing their responses before ultimately recording it. More than a half of the participants admitted that mobile Voice Thread encouraged them to think in greater depth and responded with clarity and accuracy. Almost unanimously, students responded that Voice thread developed not only speaking skills; mobile Voice Thread assignments allowed them to get to know each other better and provided personal development. They felt that hearing their peers' voices, seeing their faces, and sometimes seeing their surroundings helped them to get to know their group mates. However there were 5 students who mentioned that mobile VoiceThread didn't increase interest and engagement in the course content. They stated that mobile VT is an old-fashioned tool in contrasting to social sites such as Instagram or Facebook which provide richer opportunities for enhancing speaking skills.

\section{Discussion}

Learning is a socially mediated process (Anwas et al., 2020), requiring that we take part in meaningful interactions with peers and pertinent content. Thus, the challenge we confront in this article is finding a way to build community and discussion in online coursework. Number of researches suggests that student curiosity through mobile manipulation and exploration of information might sustain and increase learning when students are in charge of their learning environment (Scibora et al., 2018; Kompen et al., 2019). In asynchronous coursework, often students are asked to respond to one another's written contributions via Discussion Board. We contrast the traditional online discussion board with mobile VoiceThread to examine students' preference of one tool versus another and ways the use of oral communication rather than written may boost a sense of community (Kirby \& Hulan, 2016; Barhoumi, 2017; Delmas, 2017).

The use of a mobile application similar to studied VoiceThread integrated with numerous webbased information processing and communication functions allows for maximum individualization of training (Camacho-Martí \& Gutiérrez-Esteban, 2018). Students avoid unpleasant emotions associated with publicly demonstrating mistakes and correcting them, and receive more positive and supportive 
emotions, as well as more sincere support from other students (Bugawa \& Mirzal, 2018). Using a multifunctional application with the ability to format content "on the fly" allows teachers and students more efficiently, quickly and efficiently use university and public online libraries (Bajpai et al., 2016). This study did not specifically address individual factors that form a high positive assessment of the use of VT, therefore, identifying these factors, such as avoiding public assessment of the results, may be an important part of future research.

The use of online platforms and, in particular, mobile applications, both as part of such platforms and separately, for the development of speaking and listening skills in a foreign language has been studied many times (Mantikayan \& Abdulgani, 2017; Bugawa \& Mirzal, 2018). Some aspects of learning were investigated, for example, the formation of collaborative work on pronunciation, communication with native speakers using mobile communications, the use of online dictionaries and other means of checking, monitoring and developing oral and written speech in a mobile device (Safargalina, 2018; Hanbidge et al., 2018). This study focuses on better coverage of the characteristics of oral learning in general using an integrated mobile platform. All of these studies have demonstrated an increase in qualitative and quantitative indicators in language learners, which is also in line with the results of our study.

Our research, as a more generalized one, is related to the constant development of the landscape of available opportunities and services for mobile learning (Crompton, 2017; Qureshi et al., 2020). As it changes almost every year, more research is needed to evaluate more integrative teaching methods that implement more capabilities at the same time within a single platform (Mantikayan \& Abdulgani, 2017). A striking example of new technical capabilities and new teaching methods can be the use of mobile and web games as a platform for language learning (Elaish et al., 2018), the use of blogging as a base for training linguistic and communication skills (Phillips, 2017; Martin \& Broadley, 2018; Stoller, 2018). The researchers also note what is also consistent with the results of our study: oral communication skills and foreign language proficiency as the main goal and the most important skill that determines the development of students in mobile technologies (Palmer, 2019).

\section{Conclusion}

The study is devoted to the study of the results of the application of the multifunctional web and mobile application VoiceThread for the integrative development of oral skills of students of Russian universities. The study involved 44 full-time bachelor students in non-linguistic departments of University of Tyumen, Russia (students came from Russian (84\%), Kazakhstan, Uzbekistan, and Ukraine). 12 females and 2 males made up the control class and were engaged in English learning process without the use of mobile version of VT. A total of 30 students ( 15 females and 7 males) in two treatment classes (with 15 students in each), used mobile VT to develop oral skills and unlimited English language learning. All students had a pre-intermediate level. The results were evaluated in the survey according to the Likert scale. The majority of participants agreed that mobile Voice Thread contributed to the development of speaking skills $(\mathrm{M}=4.75)$ and students enjoyed using of this mobile application for language learning $(\mathrm{M}=4.13)$. According to the responses of the students their VT recordings have become more meaningful and well thought $(\mathrm{M}=3.98)$. Students' preparation for assessments on mobile VT also has become more intensive. Correlation with additional oral practice was recorded for each task $(\mathrm{M}=3.82)$. Also, students were additionally trained on responses from their classmates $(\mathrm{M}=3.53)$. The graduates have demonstrated greater focus on meaningful results assignments than the undergraduates, who were more focused on the equipment and the time spent. In practice, the research results can be used to implement mobile platforms for teaching oral language skills to students with basic knowledge of a foreign language. Based on the findings of this study, the use of mobile VoiceThread in online coursework did, in fact, further learning to determine the individual factors of increasing the effectiveness of each type of foreign language skills. 


\section{REFERENCES}

Abd Halim, M., Foozy, C. F. M., Rahmi, I., \& Mustapha, A. (2018). A review of live survey application: SurveyMonkey and SurveyGizmo. JOIV: International Journal on Informatics Visualization, 2(4-2), 309-312.

Allen, D., \& Tanner, K. (2006). Rubrics: Tools for making learning goals and evaluation criteria explicit for both teachers and learners. CBE Life Sciences Education, 5(3), 197-203. doi:10.1187/cbe.06-06-0168 PMID:17012210

Anwas, E., Sugiarti, Y., Permatasari, A., Warsihna, J., Anas, Z., Alhapip, L., Siswanto, H. W., \& Rivalina, R. (2020). Social Media Usage for Enhancing English Language Skill. International Journal of Interactive Mobile Technologies, 14(07), 41. doi:10.3991/ijim.v14i07.11552

Averkieva, L., \& Kachalov, N. (2020). Internet technologies in foreign language learning. International Journal of Social Science and Humanity, 4(2), 50-56.

Bajpai, R. P., Hada, K. S., \& Bajpai, G. (2016). Academic Libraries and E-Learning: Initiative and Opportunities. International Journal of Library and Information Science, 5(3).

Barhoumi, C. (2017). Analysis of technological, individual and community factors influencing the use of popular Web 2.0 tools in LIS education. The Electronic Library, 35(5), 977-993. doi:10.1108/EL-03-2016-0069

Bower, M. (2015). A typology of Web 2.0 learning Technologies. Educause. https://library.educause.edu/ resources/2015/2/a-typology-of-web-20-learning-technologies

Brezeanu, T. (2020). Web 2.0 Potential To Support Soft Skills Development. In The International Scientific Conference eLearning and Software for Education (Vol. 2, pp. 583-588). "Carol I" National Defence University.

Bugawa, A. M., \& Mirzal, A. (2018). The impact of Web 2.0 technologies on the learning experience of students in higher education: A review. International Journal of Web-Based Learning and Teaching Technologies, 13(3), 1-17. doi:10.4018/IJWLTT.2018070101

Camacho-Martí, M., \& Gutiérrez-Esteban, P. (2018). Harnessing the power of mobile personal learning environments (mPLEs) in next-generation teacher education. Innovation Arabia, 11, 24.

Crompton, H. (2017). Moving toward a mobile learning landscape: Presenting a mlearning integration framework. Interactive Technology and Smart Education, 14(2), 97-109. doi:10.1108/ITSE-02-2017-0018

Dahlstrom-Hakki, I., Alstad, Z., \& Banerjee, M. (2020). Comparing synchronous and asynchronous online discussions for students with disabilities: The impact of social presence. Computers \& Education, 150, 103842. doi:10.1016/j.compedu.2020.103842

Davies, P. (1999). What is evidence-based education? British Journal of Educational Studies, 47(2), 108-121. doi:10.1111/1467-8527.00106

Delmas, P. M. (2017). Using VoiceThread to create community in online learning. TechTrends, 61(6), 595-602. doi:10.1007/s11528-017-0195-z

Dugartsyrenova, V. A., \& Sardegna, V. G. (2017). Developing oral proficiency with VoiceThread: Learners' strategic uses and views. ReCALL: the Journal of EUROCALL, 29(1), 59-79. doi:10.1017/S0958344016000161

Elaish, M. M., Ghani, N. A., Shuib, L., \& Al-Haiqi, A. M. (2018). Mobile games for language learning. In Mobile Applications and Solutions for Social Inclusion (pp. 137-156). IGI Global. doi:10.4018/978-1-5225-5270-3.ch006

Hanbidge, A. S., Tin, T., \& Sanderson, N. (2018). Information Literacy Skills on the Go: Mobile Learning Innovation. Journal of Information Literacy, 12(1).

Kirby, E. G., \& Hulan, N. (2016). Student perceptions of self and community within an online environment: The use of VoiceThread to foster community. Journal of Teaching and Learning with Technology, 5(1), 87-99. doi:10.14434/jotlt.v5n1.19411

Kompen, R. T., Edirisingha, P., Canaleta, X., Alsina, M., \& Monguet, J. M. (2019). Personal learning Environments based on Web 2.0 services in higher education. Telematics and Informatics, 38, 194-206. doi:10.1016/j. tele.2018.10.003 
Mantikayan, J. M., \& Abdulgani, M. A. (2017). Enhanced Active Learning Experience through Web 2.0. CCSPC $R \& D$ Journal, 1(1), 93-114.

Martin, R., \& Broadley, T. (2018). New Generation Distributed Learning: Models of connecting students across distance and cultural boundaries. Australian and International Journal of Rural Education, 28(1), 55-72.

Metruk, R. (2018). Ethical issues in the assessment of speaking skills. Communications-Scientific letters of the University of Zilina, 20(1A), 101-114.

Okello-Obura, C., Ssekitto, F. (2015). Web 2.0 technologies application in teaching and learning by Makerere University academic staff. Library Philosophy and Practice (e-journal), 1248.

Palmer, E. (2019). Why we have to teach oral communications. Social Studies Review, 58, 50-53.

Phillips, B. (2017). Student-produced podcasts in language learning-exploring student perceptions of podcast activities. IAFOR Journal of Education, 5(3).

Qureshi, M. I., Khan, N., Gillani, S. M. A. H., \& Raza, H. (2020). A Systematic Review of Past Decade of Mobile Learning: What We Learned and Where to Go. International Journal of Interactive Mobile Technologies, 14(06), 67-81. doi:10.3991/ijim.v14i06.13479

Regmi, P. R., Waithaka, E., Paudyal, A., Simkhada, P., \& Van Teijlingen, E. (2016). Guide to the design and application of online questionnaire surveys. Nepal Journal of Epidemiology, 6(4), 640-644. doi:10.3126/nje. v6i4.17258 PMID:28804676

Safargalina, A. (2018). Teaching Speaking in EFL Environments. The TESOL Encyclopedia of English Language Teaching, 1-6.

Sahin Kizil, A. (2017). Exploring EFL learners' use of Web 2.0 tools: Preliminary findings. Pamukkale University Journal of Social Sciences Institute, 2017(27), 28-40. doi:10.5505/pausbed.2017.71602

Scibora, L. M., Mead, T. P., \& Larson, C. (2018). The influence of iPads on course performance and student perceptions of learning in human anatomy. Journal of Teaching and Learning with Technology, 7(1), 108-124. doi:10.14434/jotlt.v7i1.23973

Stoller, P. (2018). Adventures in blogging: Public anthropology and popular media. University of Toronto Press.

Suartama, I., Setyosari, P., Sulthoni, S., \& Ulfa, S. (2020). Development of ubiquitous learning environment based on Moodle Learning Management System. International Journal of Interactive Mobile Technologies, 14(14), 182. doi:10.3991/ijim.v14i14.11775

Taylor, L., \& Galaczi, E. (2011). Scoring validity. In Examining speaking: Research and practice in assessing second language speaking (pp. 171-233). Cambridge University Press.

Virtanen, J., \& Rasi, P. (2016). Integrating Web 2.0 Technologies into Face-to-Face PBL to Support Producing, Storing, and Sharing Content in a Higher Education Course. The Interdisciplinary Journal of Problem-Based Learning, 11(1), n1.

Vulfovich, E. V. (2017). «Flipped Classroom» for Organization of EFL Students' Independent Work. Higher Education in Russia, 4, 88-95.

Xie, J. (2016). Digital Storytelling to Promote EFL Students' Motivation and Efficiency in Content-Based Classroom. Education Journal, 5(6), 166. doi:10.11648/j.edu.20160506.17

Yanagi, M., \& Baker, A. A. (2016). Challenges experienced by Japanese students with oral communication skills in Australian Universities. TESOL Journal, 7(3), 621-644. doi:10.1002/tesj.229

Zeng, S. (2015). English Learning with Web 2.0: An Investigation into Chinese Undergraduates' Technology (Non)-Use and Perspectives [Unpublished Doctoral Dissertation]. UCL Institute of Education. 


\section{APPENDIX 1}

\section{Sample VoiceThread Assignment}

Click on the link above or copy and paste to your browser. After you sign in, click on the class group on the left of your screen to see this week's VoiceThread.

Before you start, review the conjugation of the present tense with the following pronouns: I, he, and she.

There is a family tree on the VoiceThread. Pretend you are one of the persons on the family tree and record your voice giving information about yourself and two other members of your family. Circle each person as you talk about him/her.

Record three complete sentences about yourself and four sentences about two other members. It is important that you use a verb with each of your sentences.

Verbs and sample texts provided on the VoiceThread are to help you come up with your own sentences. Feel free to use them but you do not have to only use the ones I provided.

Feel free to listen to my own recording as well as those of your classmates as many times as you wish before making your own contribution.

\section{APPENDIX 2}

\section{Attitude and Engagement Questionnaire}

\section{5= Strongly agree 4= Agree 3= Neutral 2= Disagree 1=Strongly Disagree}

\begin{tabular}{|c|c|c|c|c|c|}
\hline & $5 \mathrm{SA}$ & $\begin{array}{l}4 \\
\mathbf{A}\end{array}$ & $\begin{array}{l}3 \\
\mathbf{N}\end{array}$ & $\begin{array}{l}2 \\
\text { DA }\end{array}$ & 1 SD \\
\hline \multicolumn{6}{|l|}{ 1. I like using VoiceThread for language learning } \\
\hline \multicolumn{6}{|l|}{ 2. VoiceThread helped develop my speaking skills } \\
\hline \multicolumn{6}{|l|}{ 3. VoiceThread helped me develop my pronunciation } \\
\hline \multicolumn{6}{|l|}{$\begin{array}{l}\text { 4. I practiced my speaking assignment before recording it on } \\
\text { VoiceThread }\end{array}$} \\
\hline \multicolumn{6}{|c|}{$\begin{array}{l}\text { 5. Listening to other people on Voice Thread helped me develop my } \\
\text { speaking skills }\end{array}$} \\
\hline \multicolumn{6}{|l|}{ 6. Recording my voice helped me develop my speaking skills } \\
\hline \multicolumn{6}{|l|}{$\begin{array}{l}\text { 7. My recordings on VoiceThread are more meaningful and well } \\
\text { thought }\end{array}$} \\
\hline \multicolumn{6}{|c|}{$\begin{array}{l}\text { 8. It's easier for me to record my speech on Voice Thread than speak } \\
\text { face to face }\end{array}$} \\
\hline \multicolumn{6}{|l|}{ 9. VoiceThread is easy to use } \\
\hline 10. I enjoyed listening to my group mates on VoiceThread & & & & & \\
\hline
\end{tabular}


Zemlyanova Maria is a PhD of Pedagogy, Associate Professor of the Centre of Foreign Languages and Communication Technologies, University of Tyumen, Tyumen, Russia. Her research interests include mobile learning, foreign language learning, oral skills development, learning applications for learning languages.

Muravyeva Natalia is a Senior Lecturer of the Centre of Foreign Languages and Communication Technologies, University of Tyumen, Tyumen, Russia. Her research interests include mobile learning, foreign language learning, oral skills development, learning applications for learning languages.

Masterskikh Svetlana is a PhD of Philology, Associate Professor of the Centre of Foreign Languages and Communication Technologies, University of Tyumen, Tyumen, Russia. Her research interests include mobile learning, foreign language learning, oral skills development, learning applications for learning languages.

Shilova Lyudmila is an Associate Professor of the Centre of Foreign Languages and Communication Technologies, University of Tyumen, Tyumen, Russia. Her research interests include mobile learning, foreign language learning, oral skills development, learning applications for learning languages.

Shevtsova Anna is a PhD of Philology, Associate Professor of the Centre of Foreign Languages and Communication Technologies, University of Tyumen, Tyumen, Russia. Her research interests include mobile learning, foreign language learning, oral skills development, learning applications for learning languages. 